\title{
Isabel TERÁn ELIzONDO. La sátira y otras formas de crítica o subversión en la literatura novohispana. México, D.F.: Factoría Ediciones, 2015.
}

En esta colección de estudios hechos a lo largo de años (y también algunos nuevamente elaborados), la doctora Isabel Terán llama atención a la importancia de este ángulo de visión para el pensamiento de la población novohispana bajo el régimen español. Como dijo José Joaquín Fernández de Lizardi en 1822 en una colección manuscrita de poesías, la sátira es más apropiada que la poesía panegírica porque «siempre es verdadera y carece de la lisonja, o hipérboles, de que (por lo regular) se visten los elogios». Es decir, bajo condiciones coloniales la sátira que corría al lado de la literatura oficial permitía que se disfrazaran las mentiras de ella y que se expresara la verdad.

Terán destaca las obras de Fernández de Lizardi en tres de los trece ensayos de su libro. Lizardi (17761827), novelista y comentarista social en sus periódicos, obras teatrales, poesías, etc. demuestra en su producción literaria su experiencia de la transición de su país desde el colonialismo hacia la independencia. Las obras de él revelan las tensiones entre deseos de expresar verdades crueles y los confines de preferencias literarias y la censura. El récord de sus publicaciones traza cómo se estaban aflojando limitaciones sobre la expresión doméstica al mismo tiempo que surgían nuevas restricciones nacidas de temores de la influencia revolucionaria francesa y preocupaciones por el pensamiento nuevo colonial.

En su introducción a la colección Terán cuidadosamente documenta una genealogía para la sátira en México. Rescata el discurso de Teodoro Torres (1941) ante la Academia Mexicana de la Lengua, y enfatiza la importancia de los estudios de José Miranda y Pablo González Casanova sobre la sátira anónima en el siglo XVIII - popular y erudita. Acusa la contribución de Monelisa Lina Pérez Marchand (1945) quien basó su investigación sobre los mismos años en papeles de la Inquisición, señalando el papel de esa institución en controlar esta forma de expresión oral e impresa.
Terán generaliza el modo a base de su aparición en México, pero también lo particulariza enfatizando la contextualidad de cada versión. Así toma en cuenta «la autoría, la forma de transmisión y la recepción» (21). La élite intelectual pero también la colectividad popular producía la sátira. Esta se podría divulgar clandestinamente por medio de personas selectas o públicamente en formas callejeras. El tono podría ser calculadamente sofisticado o humorísticamente obsceno. No todas las sátiras estaban dirigidas hacia los españoles; las había, por ejemplo, entre miembros de las órdenes religiosas, y sátiras de los sacerdotes militares insurgentes (como Miguel Hidalgo).

Terán considera varias formas de crítica: La sátira podía basarse en la burla, la ironía, la ridiculez. La subversión podía esconderse en el barroquismo de poesías elegantes o en coplas orales; el libelo podía desaparecer en bellezas retóricas. Escritos intercambiados secretamente o lanzados con su mensaje impreso, pasquines colocados en sitios públicos, canciones populares o realmente composiciones de autores quienes escondían su identidad tras el disfraz del "pueblo» - todas las formas contribuyeron a hacer surgir un clima de oposición que por fin corroyeron lealtades previas y destruyeron autoridades. La moralidad superior que así prevalecía justificaba la destrucción del orden establecido. De hecho, en un ensayo publicado en Revista Iberoamericana (enerojunio 2007), «Espacios públicos descolonizados: la hoja volante», estudié cómo esta forma democratizó lo que antes era la propiedad del gobierno. En los últimos años del régimen español los edictos oficiales cedieron a voces nuevas; las ilustraciones en muchas de estas hojas volantes o pasquines enseñaron nuevas lecciones al público iletrado.

En un estudio nuevo de su colección Terán se enfoca en una sátira manuscrita anónima, poco estudiada - "Cosa del mundo. Diálogo entre Matraca e Illescas» contra don Pedro Nogales Dávila, obispo de Puebla entre 1708 y 1721. En el diálogo parcialmente 
en verso un cura, Salazar, defiende al obispo contra las acusaciones de dos comerciantes del mercado del Baratillo, Jusepe Matraca (vendedor de frioleras) y Bernardo de Illescas (mercader de libros). Pero se puede entender que la defensa del cura es débil, que realmente las acusaciones de los comerciantes son justas. El texto entró en la oficina de la Inquisición en 1715 para su evaluación, ahora se conserva en el Archivo General de la Nación (México), Ramo Inquisición. Terán especula que el autor fuera un sacerdote criollo «con cierta educación» (46), crítico del obispo peninsular. Según evidencia histórica de otras fuentes el obispo traficaba en favores eclesiásticas, robaba a los pobres de Puebla, e incluso tomaba para sí dineros que debiera haber enviado al rey. Sin embargo, el autor culpa al rey borbónico Felipe V por haberle nombrado a su puesto, diciendo que el monarca anterior austriaco, Carlos II, había sido mejor rey y nunca se habría confiado en tal persona.

El libro de la doctora Terán tiene el gran mérito de desentrañar la historia de la sátira mexicana de influencias europeas, de establecer sus raíces en condiciones coloniales y demostrar su justificación distinta. Es cierto que escritores clásicos como Juvenal, novelistas españoles de la picaresca, escritores satíricos espańoles como Quevedo y Torres Villarroel, y moralistas de varios países europeos afectaron a los escritores mexicanos. Pero la realización de su comunicación tuvo lugar en México; su público estuvo en México; los controles sobre su acceso a lectores y oyentes eran función de externalidades peculiares a la colonia. Terán considera el trabajo de Edward W. Coughlin quien ha escrito sobre la sátira en el siglo XviII en Espańa, localizando la preferencia por el modo allí en "el espíritu crítico reformista de la Ilustración y una poética neoclásica» (41). Sin descartar por completo esas influencias externas Terán -en su énfasis en el por qué autóctono del modo, en la praxis de teorías artísticas- establece definitivamente la lógica histórica de su desarrollo en México.

Más, e importante - en uno de sus ensayos en la colección «Algunas huellas literarias del inconformismo criollo», Terán discute la proliferación de catecismos satíricos. En éstos ve a un nivel la crítica de dignidades locales, pero también a otro nivel cuestionamiento del uso en Nueva España de lenguaje dictado y forzado - de juramentos, de oraciones, de letanías, de confesiones, etc. La dependencia de la administración colonial (civil y religiosa) en recitaciones que así vinculaban estrechamente al individuo a los centros de poder peligrosamente vaciaban capacidades de pensamiento independiente. Recitadas tal vez mecánicamente, pero no inocentes, estas revelan para nuestro entendimiento hoy en día la manera en que los medios de comunicación (entonces y ahora) no son neutrales; pueden sofocar semillas de pensamiento alternativas.

La palabra en sus varias formas prestigiosas -expresión sagrada o la literatura vernácula que estaba apareciendo entonces entre las clases élitesexige constante cuestionamiento de sus lecciones de poder. Entonces, la manera ejemplar en que los mexicanos utilizaron la parodia de los catecismos para la perversión y la resistencia en sus propias actuaciones es una lección útil aun para nosotros.

Nancy Vogeley Universidad de San Francisco (California) 